\title{
Thematic Progression in Students' Descriptive Texts
}

\author{
Mega Wati Dewi ${ }^{1}$, Khauriena Fratami Hernawan ${ }^{2}$, Yanuarti Apsari ${ }^{3}$ \\ ${ }^{1}$ IKIP SILIWANGI \\ ${ }^{2}$ IKIP SILIWANGI \\ ${ }^{3}$ IKIP SILIWANGI \\ ${ }^{1}$ watidewimega@gmail.com, ${ }^{2}$ kharienalatifah222@ gmail.com, ${ }^{3}$ yanuar.apsari1@ gmail.com
}

\begin{abstract}
This research aims to find out types of thematic progression pattern used by students in writing descriptive text and to know the dominant thematic progression used in students' writing descriptive text. This research employed a descriptive-qualitative research design. The respondents of the research were eleven grade students of SMKN 1 Cimahi. The data collection was documentation. The source of the data was descriptive texts written by students of Instrumentasi Otomatisasi Process-D. There were 9 texts written by the respondents. The collected data was analyzed by using the theory from Bloor \& Bloor (2013) as the theoretical to analyze the data. The result of this research found that students used three types of Thematic Progression in students' writing descriptive text, they are Constant Theme, Linear Theme, Split Rheme. Furthermore, Constant Theme is the most frequent themes used in students' writing descriptive text.
\end{abstract}

Keywords: Thematic Progression, Descriptive Text

\section{INTRODUCTION}

A good of writing refers to relation theme and rheme composition. The Theme is followed by the Rheme," the remainder of the message, the part in which the Theme is developed" (Halliday, Michael, Matthiessen, \& Christian, 2004: 64). With the theme can help the students to communicate. In other definition, theme is a major system that involved a clause in a message and rheme is the part that theme is developed (Lipson \& Maxine, 2004).

Content is also the importance in writing. Content includes the vocabulary, grammatical structure. A good content consists of cohesive and coherent information that make the reader understand the message easily (Mulatsih, 2005). Students can create a good writing skill with pay attention to thematic progression patterns. It means students need to be aware in their text must consist of theme and rheme in thematic progression patterns. The Rheme is the remainder of the message in a clause in which the Theme is developed, which means the Rheme typically contains unfamiliar or new information. As a message structure, a clause consists of a Theme accompanied by a Rheme and the structure is expressed by the order whatever is chosen as the Theme is put first (Halliday et al., 2004: 65).

In other definition, Halliday and Matthiessen about theme and rheme can be understood that theme is a basic point in a clause and rheme is the explanation of the theme. Based on the definition above, the researcher can conclude that theme is the beginning of the information than rheme is the explanation of the information of theme message. 
Developing clauses by theme and rheme in a text must be attented in cohesion and coherence of the text. Paltridge $(2000: 148)$ states that thematic progression is one best method to develop a text by using continuous information based on the theme or rheme. Thematic progression can keep cohesion and coherence of sequence information. In addition, (Lipson \& Maxine, 2004) defines thematic progression pattern is a way in writing that affects cohesion and coherence of a text.

There are three patterns of thematic progression namely constant theme, linear theme, and split theme.

1. Theme reiteration. (Bloor \& Bloor, 2013) state that constant theme shows the first theme that is carried on and used at the beginning of the next clause which means that the clauses repeat the first theme as its main topic. In other definition, ((Alonso-Belmonte \& McCabeHidalgo, 1998) state that constant theme is set up by the theme of the first clause that is selected as the following theme at next clauses. In other states

Table 1

Example of Costant Theme

\begin{tabular}{ll}
\hline \multicolumn{1}{c}{ THEME } & \multicolumn{1}{c}{ RHEME } \\
\hline Smoking & can give some bad impacts on people. \\
Smoking & effects both the smoker or non-smoker. \\
It & can cause some diseases. \\
The rule of smoking & must be analyzed deeper by the \\
& government.
\end{tabular}

2. Linear theme. Bloor \& Bloor (2013) defines linear theme is used when the important message in rheme is carried on into following clause as a theme. In other definition,Paltridge (2000: 149) defines linear theme as the connection relations between the first rheme and the following theme.

Table 2. Example of Linear Theme

\begin{tabular}{ll}
\hline \multicolumn{1}{c}{ THEME } & \multicolumn{1}{c}{ RHEME } \\
\hline One of the biggest natural disaster & is earthquake \\
An earthquake & can impact a great damage \\
The damage & effects some aspects such as economic, \\
& social life,etc. \\
Those aspects & are very essential for human-life \\
\hline
\end{tabular}

3. Split rheme. Bloor \& Bloor (2013) states that split rheme is a development of rheme that has much important informations which can be used as next themes in subsequent clauses. Additionally, (Brian Paltridge, 2000: 150)defines split rheme is a construction of a clause when a rheme of the first clause contains more than one ideas and it can be developed in some subsequent clauses. 
Table 3. Example of Split Theme

\begin{tabular}{ll}
\hline \multicolumn{1}{c}{ THEME } & \multicolumn{1}{c}{ RHEME } \\
\hline When Japanese people & write their language \\
They & use a combination of two separate \\
The two alphabets & alphabets as \\
The Chinese ideograms & well as ideograms borrowed by \\
& Chinese. \\
& are called hiragana and katakana.
\end{tabular}

Based on the above statements, it can be concluded that the thematic progression pattern is the thing important to creating the sentence, especially in the writing process. In this research, the researcher interesting in analyzing thematic progression pattern in student's writing descriptive text. Thus, the research aims to find out thematic progression pattern use in student's writing descriptive text and to know the dominant thematic progression use in students' writing descriptive text.

\section{METHOD}

The research was conducted at SMK N 1 Cimahi. The located at Jl. Mahar Martanegara No. 48 Leuwigajah. The research used the descriptive qualitative method.(Perry, 2005 as citied in Kuswoyo, 2016) qualitative research is characterized by the verbal description of its data The data of the study were taken from students' text of students in class XI D of SMK N 1 Cimahi in majoring Instrumentasi and Otomatisasi Process. The participants who became the sample of this research consists of nine students, three high students, three middle students, and three law students.

The technique of collecting data in this research was documentation. The source of the research was students' writing text. There were 9 texts written by the respondents. The respondents of this research were eleventh grade students of SMKN 1 Cimahi. then, in the analyzing the data, the researchers integrated and related the the data to the background of the study, mainly to the research questions, theories, and the methodology for classifying the data into manageable units as proposed by Emilia (2008, cited in Apsari, 2018). The data analysis used some steps: 1) getting the text from the students 2) reading the text 3) coding the text based on clause 4) finding the theme and rheme 5) identified the thematic progression in the texts 6) classified into three types of thematic progression pattern: constant theme pattern, linear theme pattern, split rheme pattern.

\section{RESULTS AND DISCUSSION}

\section{Results}

In this section, there are nine texts of student's writing in the descriptive text were selected to be analyzed in this research. These texts were divided into three levels of achievement: high achiever, middle achiever, and low achiever. After analyzing the data, the researcher find out the thematic progression of students writing descriptive text below. 
Table 4. Result of Constant Theme

THEME

My mother $\longrightarrow$
THEME 1
is a very beautiful women

RHEME 1

\begin{tabular}{|c|c|}
\hline$\downarrow \quad$ Her name & is Ahadina Sugihari \\
\hline THEME 2 & RHEME 2 \\
\hline $\begin{array}{l}\downarrow \\
\downarrow \\
\text { THEME } 3\end{array}$ & $\begin{array}{l}\text { is } 162 \mathrm{~cm} \\
\text { RHEME } 3\end{array}$ \\
\hline $\begin{array}{ll} & \text { Her weight } \\
\text { THEME } 4\end{array}$ & $\begin{array}{c}\text { is } 55 \mathrm{~kg} \\
\text { RHEME } 4\end{array}$ \\
\hline
\end{tabular}

Based on the analysis, the text above used Constant Theme. The students used these types is to describe "my mother" as the first theme and describe the theme in the first rheme becomes the important information that the students want to develop the topic.

Table 5. Result of Linear Theme

\begin{tabular}{|c|c|c|}
\hline THEME & & RHEME \\
\hline I & $\longrightarrow$ & will describe my family \\
\hline My family & $\Rightarrow$ & Consists of 5 members \\
\hline They & $\longrightarrow$ & $\begin{array}{c}\text { are my father, my mother, and my } \\
\text { older brother }\end{array}$ \\
\hline
\end{tabular}

Based on the analysis above, the students' text used Linear Theme. The students develop the idea from the previous rheme becomes the theme in the current clause.

Table 6. Result of Split Theme

She


After analysis, this text above, the researcher find out Split Rheme in students' text. The students used split rheme when the students have the important message in the first rheme then in the second theme students used from the first rheme becomes the second theme. This table can be seen the finding of the analysis students text in the table below.

Table 7. Types of Thematic Progression in Descriptive Text

\begin{tabular}{|c|c|c|c|c|c|c|c|c|}
\hline \multirow[t]{3}{*}{$\begin{array}{l}\text { Types of } \\
\text { Theme }\end{array}$} & \multicolumn{6}{|c|}{ Students Text Category } & \multicolumn{2}{|c|}{ Total } \\
\hline & \multicolumn{2}{|c|}{ High Achiever } & \multicolumn{2}{|c|}{ Middle Achiever } & \multicolumn{2}{|c|}{ Low Achiever } & \multirow[b]{2}{*}{$\mathrm{F}$} & \multirow[b]{2}{*}{$\%$} \\
\hline & $\mathrm{F}$ & $\%$ & $\mathrm{I}$ & $\%$ & & $\%$ & & \\
\hline $\begin{array}{l}\text { Constant } \\
\text { Theme }\end{array}$ & 26 & 90 & 44 & 93.6 & 28 & 87.5 & 98 & 90.7 \\
\hline $\begin{array}{l}\text { Linear } \\
\text { Theme }\end{array}$ & 1 & 3.4 & 2 & 4.2 & 4 & 12.5 & 7 & 6.48 \\
\hline $\begin{array}{c}\text { Split } \\
\text { Theme }\end{array}$ & 2 & 6.8 & 1 & 2.1 & - & - & 3 & 2.77 \\
\hline TOTAL & 29 & 100.2 & 47 & 99.9 & 32 & 100 & 108 & 99.95 \\
\hline
\end{tabular}

\section{Discussion}

The table above describes the result of thematic progression (Constant Theme, Linear Theme, Split theme) are used in the students writing descriptive texts. Based on the table above, the Constant Theme is the most frequent themes used. That occurs 98 times or equals is $90.7 \%$ of the total. That the high number of Constant Theme in students' that have ability maintaining the focus of the theme that is carried on and used at the beginning of the next clause. In addition, it was revealed that constant theme mostly found in the middle achievers' texts that is 44 times, then in the low achievers' that is 28 times, and the low achievers' that is 26 times.

The second pattern in students' descriptive text is Linear Theme pattern. Linear Theme pattern happens 7 times or equals $6.48 \%$ of the total. The finding is the high-frequency students' used theme of the subsequent clauses uses the rheme in the previous clause. In terms of students' level, Linear Theme pattern mostly found in the low achievers' texts that is 4 times, then followed in the middle achievement that is 2 times, and the high achievers' that is 1 time.

The third pattern that occurs in students' writing descriptive text is Split Theme pattern. This pattern occurs 3 times or equals is $2.77 \%$ in Split Theme pattern. The students' used this pattern when rheme at the first clause is divided into two or more parts or a development of rheme that has important information which used as the next theme in subsequent clauses. In the students' level, Split Theme pattern found in the high achievers' that is 2 times, then in the middle achievers' that is 1 time, and the low achievers' not found of Split Theme pattern. 


\section{CONCLUSION}

Based on the results of the analysis, there are three types of Thematic Progression. They are Constant Theme pattern, Linear Theme pattern, and Split Theme pattern. In the table above the researcher concluded Constant Theme pattern is the most frequent Theme used in students' descriptive text. They occur 98 times or equals is $90.7 \%$ of the total, that the high

number of Constant Theme in students' that have ability maintaining the focus of the theme that is carried on and used at the beginning of next clause. The students used Constant Theme pattern tends to make the focus to repeating in the same the theme in the clause. The second pattern is most students' used in their text is Linear Theme pattern, they occur 7 times or equals $6.48 \%$ of the total. The students used this pattern that the clauses repeat the first theme as its main topic. The third pattern is Split Theme, in this pattern merely occurs 3 times or equals is $2.77 \%$ of the total. It may be the students more focus on theme and not focus on the important message in rheme. Through this paper, the researcher can be concluded that the students' mostly used Constant Theme pattern in their descriptive texts to developing the paragraph.

\section{ACKNOWLEDGMENTS}

Praise is only for Allah SWT, Lord of the world. First, the writer is deeply grateful to Him who gives her his blessing, guidance, health, ability, and opportunity to accomplish this research. Blessing and salutation be upon the most honorable prophet and messenger Muhammad SAW, his relatives and followers.

The research entitled "THEMATIC PROGRESSION IN STUDENTS' DESCRIPTIVE TEXTS".

Researchers would like to say the biggest thank you for researchers' article supervisors who always gave researchers support when conducting this research. Also, researchers would like to say thank you to IKIP Siliwangi Bandung which gave us the opportunity to publish this article. Also for the blind reviewer who were reviews this article as well as to the editorial team so this article can be published perfectly.

\section{REFERENCES}

Alonso-Belmonte, I., \& McCabe-Hidalgo, A. (1998). Theme-Rheme patterns in L2 writing. Didactica, 10(April 1997), 13-31. Retrieved from http://www.researchgate.net/publication/27571982_ThemeRheme_patterns_in_L2_writing/file/60b7d52cb11c0c0e3c.pdf

Apsari, Y. (2018). REFLECTIVE READING JOURNAL IN TEACHING WRITING. Indonesian EFL Journal, 4(2), 39-47.

Bloor, T., \& Bloor, M. (2013). The Functional Analysis of English (3rd Editio). London. brian paltridge. (2000). Making Sense of Discourse Analysis.

Halliday, Michael, Matthiessen, \& Christian. (2004). An Introduction to Functional Grammar.

Kuswoyo, H. (2016). Thematic Progression in EFL S tudents' Academic Writings : A Systemic Functional Grammar Study. 14(2), 39-45.

Lipson, \& Maxine. (2004). Exploring Functional Grammar. 
Mulatsih, D. (2005). THE USE OF THEMATIC PROGRESSION IN WRITING HORTATORY. Academic Journal PERSPECTIVE: Language, Education and Literature, 5(2), 125-136. 